\title{
THE CULT OF JUPITER AND OF JUNO REGINA IN THE RURAL AREAS OF MOESIA INFERIOR
}

\begin{abstract}
The author analyzes the occurrences of the cult of Jupiter and Juno in the rural milieu of Moesia Inferior. He concludes that most of text which are related to this cult in the whole province come from the rural area. He is connecting the mentionning of this cult with the presence of communities of cives Romani consistentes and the Roman army in the villages of Moesia Inferior.
\end{abstract}

Keywords: Jupiter, Juno, cives Romani consistentes, rural area, Romanization.

\section{INTRODUCTION}

$\mathbf{R}$ ecently, I have published an inscription from Topolog (north of Moesia Inferior), dedicated to Jupiter and to $\mathrm{Juno}^{1}$; the text had actually nothing special, but upon studying the occurrences of the texts dedicated to this divine couple in the province, I noticed that the prevalence of these sources concerned the rural setting ${ }^{2}$. Furthermore, whereas the name Jupiter is traditionally accompanied by the epithets Optimus Maximus, Juno is usually accompanied by Regina (the Queen) in the vast majority of the cases. I have provided several examples in this respect, but upon getting a better insight into this epigraphic file, I have found numerous examples, reason for which I have decided to reprise these texts in a separate study. Hence, I will briefly present the inscriptions again and I will highlight the dedicators, the context of dedicating the inscriptions and I will point out various raisons for these numerous vows in the rural areas of Moesia Inferior. I will discuss the inscriptions starting with those within the rural territories of the northern Black Sea cities, followed by those within the centre of the province (in the N-S and E-W directions) and finally, the texts from the cities situated on the Danube line and from their rural areas. I will discuss the texts where the couple is mentioned (even associated with other divinities, except for Minerva).

\section{THE EPIGRAPHIC FILE}

The rural territory of Istros provides numerous and interesting sources. A first thing worth mentioning is an official colonisation (the conuenti of ciues Romani with the communities of Thracians from the south of the Danube - the Bessi and the Lai). A. Avram did an account of the matter concerning these communities ten years ago $^{3}$. He believes that the

\footnotetext{
MIHAILESCU-BÎRLIBA 2014, 303-307.

2 See also MIHAILESCU-BÎRLIBA 2015a, 439-445.

AVRAM 2007, 91-109. Concerning the ciues Romani consistentes, see also VAN ANDRINGA 2003, 49-60.
}

\section{Lucreţiu Mihailescu-Bîrliba}

„Alexandru Ioan Cuza” University of Iași blucretiu@yahoo.com

DOI: $10.14795 /$ j.v6i2.390

ISSN 2360 - 266X

ISSN-L 2360 - 266X 
communities of Thracians, who were not indigenous, had been colonized elsewhere initially, before arriving to the region ${ }^{4}$. It is also worth noting that besides the Roman citizens and the Thracians, the inscriptions mention (in the case of uicus Quintionis) veterans retired in the rural area after having completed their service. This social element reinforces the Latinity of the rural area, at least concerning the use of Latin in the inscriptions. In any case, it should be noted that the villages are indeed organised following the Roman model of such an organisation. The formula remains the same even after the edict of Caracalla. I agree with the first situation presented by A. Avram, who sees in this reality a local tradition, as the formula had no legal significance at that point ${ }^{5}$. These rural sites were constituted in the first half of the second century, as proven by the texts. But when, more precisely? Though the first texts date to the beginning of Antonine's reign, this colonisation was achieved earlier, probably during the reign of Trajan or Hadrian. After the reinforcement of the northern side of the Danubian limes, the territory of the Greek cities on the northern Black Sea coast was inhabited by Roman citizens (veterans included), who had definitely received properties. To this segment, we add the population of colonised Thracians south from the Danube, the Bessi and the Lai. We also should not forget the Greek communities inhabiting the former chora of the Greek city. The site situated in the current village of Istros and in the chora Dagei represents evidence in this respect. In the other corners of the rural area of Istros, the bearers of Greek names (mostly surnames) are rather rare.

I will return to the topic of inscriptions dedicated to Jupiter and to Juno. I refer exclusively to the vows fulfilled by the rural community, through their magistri and questores: Claudius Ianuarius and Lupus (the second half of the second century) ${ }^{6}$ (vicus Quintionis), Maximus (magister of a vicus whose name is no longer preserved on the stone) in $187^{7}$, Aurelius Fortunatus and Aelius Herculanus in $237^{8}$, Bonosus Bonuni and Iustus Iustini in $238^{\circ}$, Claudius Antoninus and Cocceius Iustus in $247^{10}$ (vicus Secundini). To these texts, two others should be added. One of them was found on the precinct of the Cius fortress, but the stone certainly came from the territory of Istros: this was an official inscription, set up by the civitas and the region Histriae, through three archontes of the region Histriae ${ }^{11}$. The second text was recently published by V. Bottez ${ }^{12}$. Whereas the inscription (fragmentary) was found reused in the rampart of a later period of the city, the author (with whom I agree) believes it was brought from the rural setting, which is so far the origin of al the vows dedicated to the divine couple ${ }^{13}$.

I will not detail again the discussion concerning whether Ulmetum belonged to the territory of Istros, given that I did this before. I refer to an organisation similar to the other villages from the territory of Istros, to

\footnotetext{
AVRAM 2007, 99-100.

AVRAM 2007, 101.

6 ISM I, 329.

ISM I, 368.

ISM I, 346.

ISM I, 347.

ISM I, 349

ISM V, 123.

2 BOTTEZ 2014, 291.

13 BOTTEZ 2014, 291.
}

the presence of Bessi consistentes and to the fact that the inscription considered an argument for Ulmetum belonging to the territory of Capidava is probably a pierre errante, all the more since Capidava is a vicus ${ }^{14}$. Furthermore, the inscriptions dedicated to Jupiter and to Juno are set up by their magistri, who sometimes mention these communities: L. Valerius Maxellius in $140^{15}$, Flavius Germanus in $163^{16}$, Martius Philo in $172^{17}$. Nonetheless, it must be noted that this concerns the vows fulfilled by individuals who evoke these conventi personally. Concerning Valerius Maxellius, given that Valerius is a gentilicium attested mostly among the soldiers ${ }^{18}$, it may be suggested that he was a descendant of a soldier, but I cannot be sure in regards with this issue. The gentilicium of the third mayor, Martius, is found in two other cases in the village de Capidava: a woman, the wife of a certain Bassus, of Thracian origin, the mother of three characters with Thracian names, Zura, Tsiru and Tsinna ${ }^{19}$, and another person (Martius or Martia), who sets up a funerary monument for the memory of his wife (husband $)^{20}$. Martius may have been related to them. In any case, his cognomen of Greek origin indicates a descendant of a Greek-speaking from the Black Sea cities, probably Istros (the nearest). Other inscriptions dedicated to Jupiter and to Juno represent individual vows, such as the one of T. Flavius Severus ${ }^{21}$ and of magister Iulius Teres (a citizen from the community of Thracians) ${ }^{22}$. Severus is not the only Flavius of Ulmetum. One of the village magistrates, Germanus, has the same gentilicium ${ }^{23}$. Furthermore, Severus used the stone by erasing the cognomen of a person who had the same first name and the same gentilicium, and then he added his surname as the noew dedicator. A certain Flavius Augustales dedicates, on June 5, 191, an inscription for Jupiter Optimus Maximus and to Sylvan ${ }^{24}$. The Flavii constituted, consequently, a family of rather wealthy citizens of Ulmetum. All of them mention that the vows were fulfilled at their own expense. Regarding Iulius Teres, he probably belonged to the community of the Bessi. The text dates to the second century, but it is impossible to establish a more precise dating. Finally, a sixth text dedicated to the divine couple is too fragmentary to figure out the name (the names) of the dedicator $(\mathrm{s})^{25}$.

Concerning the rural territory of Tomi, it must be said that the beginning of the Roman occupation in the city manifested itself timidly in the occupation of the rural area. It may be noted that, little by little, even in the first half of the second century, the rural communities begin to have a better defined structure, as uici (with a magister or two magistri) or komai ${ }^{26}$. The population comprises Roman citizens, who inhabited, as we will see, along with the Lai.

${ }_{14}$ Voir MIHAILESCU-BîRLIBA 2015b, 143-155.

15 ISM V, 62.

16 ISM V, 63.

17 ISM V, 64

18 Dana 2011, 56-57.

19 ISM V, 27.

20 ISM V, 44

21 ISM V, 65

22 ISM V, 69

23 ISM V, 63

ISM V, 67

25 ISM V, 83

26 Concerning the administration of villages in Moesia Inferior overall, see APARASCHIVEI 2015, 27-42. See also BĂRBULESCU/BUZOIANU 2016, 196, 199 . 
Two inscriptions were found in the rural areas of Tomis. The first was set up by the veterans, the Roman citizens and the local population (Lai) residing in the vicus Turris Muca[--], through the magistri [---]us Ianuarius and Herculanus ${ }^{27}$. Given that the text mentions two emperors and given that the names seem to have been erased, the dating would be the third century. Does Herculanus have a gentilicium or is he a mere peregrine? The text is unfortunately too fragmentary to provide a more clear opinion. In any case, the text attests the conventus of cives Romani and des veterans, along with the community of Thracians (Lai). From the vicus Celeris, the magister Ulpius Ulpianus dedicates an altar for the divine couple in $177^{28}$. This vicus was identified for a long time with the modern village of Vadu (near Istros) and by consequent, ascribed to the territory of Istros. It seems, however, that the text if from Sibioara ${ }^{29}$ and that it comes from the territory of Tomis.

The rural areas of Callatis are the origin of only one inscription, dedicated by T. Flavius Sabinus to the divine couple, for the health of Antonine the Pious ${ }^{30}$. The gentilicium is rather common in the rural territory of Callatis ${ }^{31}$ : according to A. Avram, there are many Flavii in Moesia Inferior, after the period when T. Flavius Sabinus was governor towards mid first century ${ }^{32}$.

The part of the province situated between the Black Sea and the Danube line also provides several examples. The inscription of Topolog, which I mentioned in the beginning of this paper ${ }^{33}$, was dedicated by P. Lae(...) Comicus in an area that seems to be a vicus, given the epigraphic and archaeological information of the $\operatorname{area}^{34}$. At Dulgheru (Romania, east from Carsium), a certain Xenius Nicephoros set up an altar for the divine couple ${ }^{35}$. The text comes from a rural area that has not been researched thus far. The character is a peregrine from a Greek-speaking area. The stone may have been brought from the rural territory of Istros. From Dulgheru, there are two other inscriptions in $\mathrm{Greek}^{36}$ : in one of these texts, a person is also found at Ulmetum ${ }^{37}$. The vow of Nicephoros is private, but the dedicator mentions that he set this up for the health of Emperor Antonine the Pious.

A little more to the south, at Shumen (Bulgaria), a magister vici with a Thracian name (Burtinus), from Tomis (civis Tomitanus) set up in 153 an altar for Jupiter and Juno, for the health of emperors Antonine and Marcus Aurelius $^{38}$. The vow is not official; nonetheless, even as a private dedicator, Burtinus adds the formula pro salutevici; he is accompanied in the fulfilment of his promise by his son Demetrius. It should be noted that the father has a Thracian

\footnotetext{
27 ISM II, 141. The gentilicium of the mayor may be Aelius, Flavius, Iulius, not Caius (form of the surname), see ISM II, 141, subnumero and BÂLTÂC 2011. BĂRBULESCU/BUZOIANU 2013, 200, propose the form of Aelius Ianuarius, but then they choose Caius Ianuarius (BĂRBULESCU/BUZOIANU 2016, 207). I believe that the ending $u$ is more likely to belong to a gentilicium.

28 ISM I, 351.

29 DORUŢIU-BOILĂ 1964, 132.

30 ISM III, 249.

31 ISM III, 238, 242, 250.

32 ISM III, 249, subnumero.

33 MIHAILESCU-BÎRLIBA 2014, 303-307.

34 NUȚU, MIHAILESCU-BÎRLIBA 2017, 171-175, with the bibliography.

35 ISM V, 129.

36 ISM V, 128, 130.

37 Attas, son of Posses (ISM V, 78).

38 CIL III 7466.
}

name, the sons have a Greek name and the inscription is written in Latin.

At Laskar (south-east from Pleven) an extremely fragmentary text attests a vow for the divine couple, fulfilled by a certain Dionysius, a peregrine without any doubt ${ }^{39}$. The character came from a Greek-speaking family, but the stone was written in Latin.

At Dermanci (south-west from Pleven, Bulgaria), the vow for the divine couple is fulfilled by M. Aurelius Maximus, a cavalry soldier in the legio I Antoniniana in $205^{40}$. The text is not completely preserved, but this is a private vow. The legion stationed at Novae: the raison of the presence of this eques in the rural area is either for some kind a mission, or because he owned an estate. In the same region, at Dolna Bešovica, Aurelius Pudens, a strator consularis, sets up a monument for several divinities: Jupiter, Juno, the Victory, Vulcan and Mercury ${ }^{41}$. The gentilicium of Aurelius without the mention of the first name suggests a dating after 212. In his capacity as a strator, he was in charge of the governor's horses. His presence in the region has the same reasons as in the case of M. Aurelius Maximus.

Finally, in a village situated west from Montana (maybe in its territory), at Golemanovo, an optio of the legio I Italica, C. Iulius Valens, sets up an altar for Jupiter, Juno and Hercules ${ }^{42}$. Subunits of the legion were detached in the province; or maybe he owned an estate in the rural area.

I will discuss in the following lines the cities situated on the Danube line. I thus begin with Troesmis, which represented the camp of the fifth legion Macedonica. From the period when the legion first settled in, two civilian administrative units are attested, the canabae legionis and the civilian site; we note the existence and the functionality of the two units at the same time; they even had common notable citizens (e.g., L. Licinius Clemens, quinquennalis canabensium and decurio Troemensium ${ }^{43}$ ). Along with Troesmi consistentes, several texts evoke an ordo Troesmensium ${ }^{44}$. The cives Romani Troesmi consistentes set up an altar for the divine couple, through their magistri: one of the names was preserved (Geminius Aquilinus) ${ }^{45}$. In Moesia Inferior, a Geminius Herculanus is attested at Lazen (Bulgaria) ${ }^{46}$, while Geminius Herodianus, from Samaria, is mentioned at Karagac (Bulgaria) ${ }^{47}$. Another Geminius - whose surname is Severus - is featured in a list of soldiers in the territory de Montana as an evocatus ${ }^{48}$. Given that the Geminii are often attested in Italy ${ }^{49}$, it is nonetheless difficult to determine the origin of Geminius Aquilinus.

A file that is rather rich in vows for Jupiter and Juno is provided by Capidava. The numerous inscriptions prove the existence of a developed city near the camp, where several
ILB 238.
40 ILB 192
${ }^{41}$ ILB 156.
42 ILB 235
3 ISM V, 158
4 ISM V, 143-145
${ }^{45}$ ISM V, 157.
46 CIL III 6150.
7 ILB 447.
48 CIL III 14409-1.
49 CIL V 5863, 5972, 6016-6018; VI 760, 904, 2958, 7911; IX 508, 1156, 5548; X 596, 6036, 6482. See also MIHAILESCU-BÎRLIBA/DUMITRACHE 2012 103-104. 
auxiliary units were stationed ${ }^{50}$. The texts attest vexillationes of the legion V Macedonica ${ }^{51}$ and XI Claudia ${ }^{52}$, but the camp was occupied in principal by two cohorts: I Ubiorum ${ }^{53}$ and I Germanorum ciuium Romanorum ${ }^{54}$. Near the camp, there were the canabae or a vicus militaris and a civilian site. The territorium Capidauensis, mentioned in an inscription found at Ulmetum ${ }^{55}$, corroborated with the mention of a princeps loci, determined E. Doruțiu-Boilă to consider Capidava a vicus ${ }^{56}$. Nonetheless, the status of the locality is still unknown. The limits of the territory of Capidava are also unknown. Bâltâc involves the existence of territories pertaining to the centres situated near the camps of Beroe, Cius, Carsium and Axiopolis ${ }^{57}$, but it is very difficult to assess these assumptions, knowing that the last cities mentioned above were too small to have a territory. Concerning the territorium Capidauensis, I believe that it most likely represents, as P. Kovács has shown for other situations ${ }^{58}$, a rural structure under military authority (units that have stationed here). The inscriptions for Jupiter and Juno do not have an official character, and the dedicators mention twice their status of magistervici ${ }^{59}$. With one exception ${ }^{60}$, the texts contain vows for the health of the emperor(s). In two cases, Jupiter receives the epithet of Tonans, once from the part of a citizen, the second time from a person whose name is unknown: the two texts date to the reign of Antonine ${ }^{61}$. They may have been local notables. Eftacentus, the son of Bithus, is one of the magistri who dedicate altars for the divine couple ${ }^{62}$. The village is not named, but it is a site inhabited by natives (most peregrines, such as this mayor) and probably by veterans and by Roman citizens. The type of organisation seems to be the one with one mayor. An indigenous site may have been reorganised following the Roman model. The text dates to 168 . The two subsequent texts date to the reign of Commodus. They also fail to mention the name of the rural authority. The first vow was fulfilled not only for Jupiter and for Juno, but also for the genius [lo]ci or $[v i] c i^{63}$. The second inscription is from 188 and the text was almost completely erased ${ }^{64}$. Another text dates to the year 200; it is dedicated to the same divine couple and the dedicator is called Claudius Cocceius, maybe also a magister ${ }^{65}$. Because it is a private inscription, he did not find it necessary to mention his military position. Aelius Longinus dedicates an altar for the same divine couple ${ }^{66}$; he is a veteran of the ala Arauacorum, stationed probably at Carsium $^{67}$. Even if he is a citizen, the way this inscription is ${ }_{50}$ See also MUNTEANU 1970, 211-222.

51 ISM V, 54.

52 ISM V, 53

3 OPRIȘ 1997, 277-278; COVACEF 2000, 287-289; MATEI-POPESCU 2010, 235-236.

54 ISM V, 16; OPRIȘ/POPESCU 1997, 177-181; COVACEF 2000, 290-291; MATEI-POPESCU 2010, 213-215.

55 I SM V, 77.

56 ISM V, 77, subnumero.

57 BÂLTÂC 2011, 8687, 89.

58 KOVÁCS 2013, 144.

59 ISM V, 15, 56.

60 I SM V, 56

61 ISM V, 13-14.

62 ISM V, 15.

63 ISM V, 17

${ }^{64}$ ISM V, 18.

65 ISM V, 19.

66 ISM V, 23

67 ISM V, 94-95. See also MATEI-POPESCU 2010, 189-190. written (with many errors) indicates a non-Latin origin of the former soldier, maybe even an indigenous person who had obtained his citizenship during the reign of Antonine. A vicus is the one attested at Gălbiori (near Capidava); the name of the former locality is not mentioned in the text, but the magister is called Veturius Tertius ${ }^{68}$. The text is dedicated to Jupiter, Juno and Ceres Frugifera, which highlights the importance of agriculture in this region. The same character sets up an epitaph for Iulia Veneria, his wife, and for his mother Veturia Furnia ${ }^{69}$. We see that Veturius Tertius bears the name of his mother, which shows that the father was not a citizen when he was born. Another Veturia was married to M. Ulpius Piso ${ }^{70}$. They had two children: Veturia Ulpia (born when the father was not a citizen) and M. Ulpius. This stands to show that M. Ulpius Piso was a soldier in an auxiliary unit (probably the first cohort of the Ubians) and he was granted the citizenship during the reign of Trajan. This inscription seems to be older than the one attesting Veturia Furnia. We do not know the origin of these women, who use as surname a form of gentilicium. Are they somehow related to Cocceius Veturius, who transmitted his surname as gentilicium according to the Germanic tradition? It is very difficult to provide an answer to this question. Concerning the name of the village, E. Doruțiu-Boilă believes that it is a vicus Capidauensis $^{71}$, but nothing proves that Capidava was a vicus, not a civitas. We may imagine it was more likely a vicus under the authority of the military camp.

More to the south, but still on the Danube, we find the camp and the village of Sacidava. At Sacidava, the camp found harboured military units such as the cohors IIII Gallorum $^{72}$, cohors I Cilicum ${ }^{73}$ and probably vexillationes of the following legions: fifth legion Macedonica ${ }^{74}$, first legion Italica ${ }^{75}$ and eleventh legion Claudia ${ }^{76}$. Not far from Sacidava, there was a statio of beneficiarii ${ }^{77}$. The inscriptions also attest burgarii ${ }^{78}$, which also suggests the status of burgus ascribed to the fortress of Sacidava ${ }^{79}$. Aelius Castus, a former duumvir, sets up an inscription for Jupiter and for Queen Juno ${ }^{80}$. R. Cîrjan believes it is for Deus Aeternus ${ }^{81}$. Nonetheless, the group of letters EOAE does not appear to be very clear, as it has been reconstituted. Instead of an $\mathrm{O}$, it may very well have been a G. Furthermore, Castus, as a duumviral, would have mentioned his gentilicium, hence the reconstitution [R]eg(inae) Ae[1](ius) Castus seems more plausible ${ }^{82}$. Aelius Castus has probably exercised his function at Tropeaum Traiani, the nearest city. He most likely owned an estate in the rural area and it is here that he set up the inscription.

The last inscriptions that I discuss pertain to the rural areas of Novae, the canabae of the legio I Italica, the ${ }_{68}$ ISM V, 56.

69 ISM V, 35

70 ISM V, 35

1 ISM V, 56, subnumero.

ISM IV, 169, 191; see also MATEI-POPESCU 2010, 210-212.

ISM IV, 170, 172, 184, 202.

ISM IV, 175

ISM IV, 200

ISM IV, 186, 201.

ISM IV, 194

ISM IV, 179, 180.

Concerning the burgi, see VISY 2009, 989.

AE 1963, 175.

CÎRJAN 2004, 51-52.

See also AE 2004, 1270. 
civilian rural site and the surroundings. The inscriptions do not have an official character. A first text is dedicated by a veteran, C. Caeselius Vitalis ${ }^{83}$. Except for this attestation in Moesia Inferior, in Europe the occurrences of Caeselii are found in Dalmatia ${ }^{84}$ and mostly in Rome and in Italy ${ }^{85}$. This is why I argue that this veteran had an Italian origin. Finally, probably from the rural territory of the city, there are two more inscriptions, one of Obnova, dedicated by a person whose name is unknown (accompanied by the vows for the health of Septimius Severus and of Caracalla) ${ }^{86}$, and the second one of Pavlikeni, dedicated by a consular beneficiary, Aurelius Aeternalis, as an ex voto ${ }^{87}$.

I did not include seven inscriptions of this list. The first is from Novae (maybe from the rural territory), but dedicated to the capitol triad ${ }^{88}$. The other six most likely pertain to the urban areas of the cities: this is another altar set up probably by the officers of the legio I Italica at Novae ${ }^{89}$, an inscription set up by a centurion of the Eleventh legion Claudia at Montana ${ }^{90}$, a text dedicated by two duumviri quinquennales at Tropaeum Traiani ${ }^{91}$, an altar dedicated by someone whose name was not preserved at Tomis ${ }^{92}$ and two inscriptions of Durostorum dedicated by the local notables ${ }^{93}$ and by a praeses of the province in the period of the Tetrarchy ${ }^{94}$.

3. THE FORMULAS OF THE INSCRIPTIONS. SOCIAL ASPECTS OF THE CULTS OF JUPITER AND JUNO IN THE RURAL AREAS OF MOESIA INFERIOR

The texts featured above show that the vows for Jupiter and Juno in the rural areas of Moesia Inferior are actually very numerous. Out of the 43 inscriptions, 36 certainly pertain to the rural area. In the following lines, I will discuss the dedicators and the nature to the vows, and I will also attempt to point out the particularities of these inscriptions of the province compared to other regions of the Empire.

It must be mentioned from the beginning that there are two types of dedications: the collective vows (of the communities through their magistri and/or questors, with an official character) and the individual vows. Collective dedications are found exclusively in the southern part of the province, in the communities of cives Romani, veterani and Thracians residing in these villages. To these texts, we add the inscription found at Cius, but certainly pertaining to the territory of Istros, set up by the civitas and by the regio Histriae through the archontes ${ }^{95}$. The texts date from 140 (at Ulmetum) ${ }^{96}$ to 246 (vicus Secundini) ${ }^{97}$. Most of them belong to the territory of Istros (three from vicus Secundini, one from vicus Ulmetum ${ }^{98}$, one from vicus Quintionis, one from a village whose name was not preserved and the inscription found at Cius, featured above). Another text comes from the territory of Tomis (vicus Muca[--- ${ }^{99}$.

I will discuss as follows the individual dedications. There are persons with official positions, but who fulfil vows as private persons, sometimes even adding the formula de $s u o^{100}$. The formula is also featured in the vows where the dedicators are represented by the communities of citizens, veterans and Thracians (Table no 1 ).

Consequently, there are magistri that mention their position; except for the ones mentioned above (who use the formula de suo), the texts also feature Maximus (magister vici on the territory of Istros) $)^{101}$ and Eftacentus, the son of Bithus (at Capidava) ${ }^{102}$. The other dedicators with a better known status are P. Aelius Castus, former duumvir, who sets up an altar at Sacidava ${ }^{103}$, and soldiers such as M. Aurelius Maximus, eques of legio I Italica ${ }^{104}$, C. Iulius Valens, optio of the same legion ${ }^{105}$, Aurelius Pudens, strator consularis ${ }^{106}$, Aurelius Aeternalis, beneficiaries consularis ${ }^{107}$.

Table no. 1

\begin{tabular}{|c|c|c|c|c|c|}
\hline Nc & Dedicator(s) & Source & \multicolumn{2}{|c|}{ Village (ancient or modern) } & Observations \\
\hline 1 & L. ValeriusMaxellius & ISM V, 62 & \multicolumn{2}{|c|}{ vicus Ulmetum } & the vow is dedicated by the $c . R$. and Bessiconsist. \\
\hline 2 & Flavius Germanus & ISM V, 63 & \multicolumn{2}{|c|}{ vicus Ulmetum } & personal vow; magister \\
\hline 3 & Martius Philo & ISM V, 64 & \multicolumn{2}{|c|}{ vicus Ulmetum } & personal vow; magister \\
\hline 4 & T. Flavius Severus & ISM V, 65 & \multicolumn{2}{|c|}{ vicus Ulmetum } & personal vow \\
\hline 5 & IuliusTeres & ISM V, 69 & \multicolumn{2}{|c|}{ vicus Ulmetum } & personal vow; magister \\
\hline 6 & UlpiusUlpianus & ISM I, 351 & \multicolumn{2}{|c|}{ vicus Celeris } & personal vow \\
\hline 7 & Burtinus and his son Demetrius & CIL III 7466 & \multicolumn{2}{|l|}{ Shumen } & personal vow; magister \\
\hline 7 & Claudius Cocceius & ISM V, 19 & \multicolumn{2}{|l|}{ Capidava } & personal vow \\
\hline 8 & VeturiusTertius & ISM V, 56 & \multicolumn{2}{|c|}{ Gălbiori (near Capidava) } & personal vow; magister \\
\hline \multicolumn{4}{|c|}{$83 \quad \mathrm{AE} 1998,1136}$. & \multicolumn{2}{|l|}{$95 \quad$ ISM V, 123.} \\
\hline \multicolumn{4}{|c|}{$84 \quad$ CIL III 2686a, 3175; AE 1976, 532.} & \multicolumn{2}{|l|}{$96 \quad$ ISM V, 62.} \\
\hline 85 & \multicolumn{3}{|c|}{ For instance, CIL VI 2407a, 13674, 13931-13933; CIL IX 4639, 5096; X } & $97 \quad$ ISM I, 349. & \\
\hline \multicolumn{4}{|c|}{ 2192, 3448; XI 3844, 6509; XIV 477, 727-728, 2335.} & $98 \quad$ ISM V, 140. & \\
\hline \multicolumn{4}{|c|}{86 ILB 239.} & \multicolumn{2}{|c|}{$99 \quad$ ISM II, 141} \\
\hline \multicolumn{4}{|c|}{87 ILB 425.} & \multicolumn{2}{|c|}{$100 \quad$ ISM I, 351; V, 18-19, 56, 63-65, 69.} \\
\hline \multicolumn{4}{|c|}{$88 \quad$ IGLNovae 24.} & \multicolumn{2}{|c|}{$101 \quad$ ISM I, 368.} \\
\hline \multicolumn{4}{|c|}{$89 \quad \mathrm{AE} 1999,1330}$. & \multicolumn{2}{|l|}{102 ISM V, 15.} \\
\hline \multicolumn{4}{|c|}{$90 \quad$ AE $1985,746}$. & \multicolumn{2}{|c|}{$103 \quad$ AE $1963,175}$. \\
\hline \multicolumn{4}{|c|}{$91 \quad$ ISM IV, 20.} & \multicolumn{2}{|c|}{$104 \quad$ ILB 192.} \\
\hline \multicolumn{4}{|c|}{92 ISM II, 142.} & \multicolumn{2}{|l|}{105 ILB 235.} \\
\hline \multicolumn{4}{|c|}{93 ISM IV, 94.} & \multicolumn{2}{|l|}{106 ILB 156.} \\
\hline \multicolumn{4}{|c|}{94 ISM IV, 96.} & \multicolumn{2}{|l|}{$107 \quad$ ILB 425.} \\
\hline
\end{tabular}


Table no. 2

\begin{tabular}{|c|c|c|c|c|c|}
\hline No & Dedicator(s) & Formula & Source & Ancient or modern village & Dating \\
\hline 1 & civitas and region Histriae & pro sal. Imp. Aug. & ISM I, 329 & vicus Quintionis & second half of the second century \\
\hline 2 & C. R. and Lai consistentes & pro salute $\{m\} I m p$. & ISM I, 368 & Neatârnarea & 187 \\
\hline 3 & C. R. and Lai consistentes & pro salute $\mid<n>p$ & ISM I, 346 & vicus Secundini & 237 \\
\hline 4 & C. R. and Lai consistentes & pro salute Imp. & ISM I, 347 & vicus Secundini & 238 \\
\hline 6 & C. R. and Bessi consistentes & pro salute Imp. & ISM V, 62 & Ulmetum & 140 \\
\hline 7 & Flavius Germanus & pro salute Augg. & ISM V, 63 & Ulmetum & 163 \\
\hline 8 & Martius Philo & pro salute Imp. & ISM V, 64 & Ulmetum & 172 \\
\hline 9 & c. R., vet., Lais consist. & pro salutelmpp. Augg. & ISM II, 141 & vicus TurrisMuca[---] & Late second century-early third c. \\
\hline 10 & T. Flavius Sabinus & pro salute Imp. & ISM III, 249 & near Mangalia & late second century \\
\hline 12 & Burtinus and Demetrius & pro salute Imp. & CIL III 7466 & Shumen & 153 \\
\hline 13 & c. R. Troesmi consistentes & pro salute Imp. & ISM V, 157 & Troesmis & $139-161$ \\
\hline 14 & Aelius Cara[---] & pro salute Imp. & ISM V, 13 & Capidava & $139-161$ \\
\hline 15 & Anonymous & pro salue Imp. & ISM V, 14 & Capidava & $139-161$ \\
\hline 16 & Eftacentus Bit(h)i & pro salute Imp. & ISM V, 15 & Capidava & 168 \\
\hline 17 & Anonymous & pro salute Imp. & ISM V, 17 & Capidava & $180-192$ \\
\hline 18 & Anonymous & pro salute Imp. & ISM V, 18 & Capidava & 188 \\
\hline 19 & Claudius Cocceius & pro salute Imp. & ISM V, 19 & Capidava & 200 \\
\hline 20 & Aelius Longinus & pro salute Imp. & ISM V, 23 & Capidava & $161-169$ \\
\hline 21 & Anonymous & pro salute Impp. & ILB 239 & Obnova & $197-211$ \\
\hline
\end{tabular}

In the 36 texts, the persons who dedicate the monument for the divine couple - either personally or on behalf of the communities they represent - use the formula pro salute accompanied by the name (or names) of the emperor (or emperors). The Table below (Table no 2) presents these texts. I will only list the formulas, without adding (as it occurred in some situations) the names of emperors.

Another particularity is worth noting here, as in the case of collective vows: the formula (with minor spelling differences) is found almost exclusively (except for two cases) in the north of the province. As in the text of Shumen ${ }^{108}$, the dedicators are habitants of Tomis, thus they are from the north of the province. It this an epigraphic habit or is it a particularity of this side of Moesia Inferior? I will try to dedicators are mostly - if $\mathrm{w}$ do not count the communities - the magistri vici; I tend to believe that, whereas they fail to mention their status, persons such as Aelius Cara[---] ${ }^{109}$, Claudius Cocceius ${ }^{110}$ and several anonymous persons from Capidava ${ }^{111}$ are also magistri, given the context where they set up the altars and the similarities with other vows of Capidava. Concerning the formula pro salute Imp(eratoris) or Imp(eratorum), D. Fishwick notices that it is a phrase of political loyalty, of belonging to the Empire and of the emperor's image as an element of political stability; this loyalty is expressed in religious terms, as an act of pietas ${ }^{112}$. S. Nemeti draws similar conclusions concerning such formulas in Roman Dacia ${ }^{113}$.

In the aforementioned cases, not only where they use

Table no. 3

\begin{tabular}{|c|c|c|c|c|}
\hline No & Dedicator & Formula & Source & Ancient or modern village \\
\hline 1 & Flavius Germanus & pro salute sua and civi. R. and Bessis cons. & ISM V, 63 & Ulmetum \\
\hline 2 & Martius Philo & Bessis & ISM V, 64 & Ulmetum \\
\hline 3 & Iulius Teres & pro salute sua and filiorum sui (!) and vicanorum & ISM V, 68 & \\
\hline 4 & Burtinus & pro salute vici and sua and suorum & CIL III 7466 & Shumen \\
\hline 5 & Aelius Longinus & prose & ISM V, 23 & Capidava \\
\hline 6 & Aelius Castus & prose and suos & ISM V, 129 & AE 1963,175 \\
\hline
\end{tabular}

provide an answer later, in the Conclusions, after highlighting potential differences concerning the vows for Jupiter and Juno in the province. In any case, it should be noted that the ${ }_{108}$ CIL III 7466.

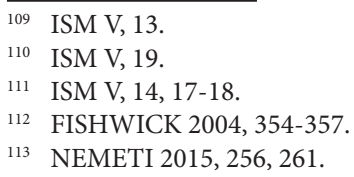


the formula pro salute Imp., certain dedicators add formulas concerning the health of their communities or personal health, or even the health of their families (Table no 3).

Again, I highlight that these formulas are found in the northern part of the province, except for the inscription of Shumen, dedicated by a civis Tomitanus. There are two texts where the dedicators set up the altar for their personal health or for that of family members, two where they set up the inscriptions for the communities and one text where they use a mixed formula (pro salutevici- or vicanorum-and sua et suorum). I believe that, as in the case of the formula pro salute Imp., the formulas with vows for the communities represent an expression of public loyalty, of belonging not only to the Empire, but also to a community grouped under a Roman form of organisation.

Finally, it is also worth noting that certain dedicators simply set up altars for the divine couple, using usual votive formulas, without adding any other details. Such persons are civilian Roman citizens (such as T. Flavius Severus ${ }^{114}$, P. Lae(...) Comicus ${ }^{115}$ ), soldiers and veterans (Aurelius Pudens $^{116}$, L. Cocceius Marcus ${ }^{117}$, C. Iulius Valens ${ }^{118}$, C. Caesellius Vitalis ${ }^{119}$, Aurelius Aeternalis ${ }^{120}$ ) and peregrines (Dionysius ${ }^{121}$ ). Soldiers fulfilled their vows while on mission or at their properties, but it is known that Jupiter was the most celebrated divinity among soldiers. I would argue that this is also an expression of loyalty for the Roman State and for the emperor.

Concerning these types of vows, a question emerges: are they the expression of a "State religion" or of personal piety? A. Rubel has argued recently that "State religion" in imperial Rome is not justified at the level of religious choices or personal cult practices ${ }^{122}$. I will not detail this dispute here; it was by no means a denial of private religion, even though the author who supported the idea of the prevalence of the "State religion" saw private religion as more of a superstitio ${ }^{123}$. Rubel uses the phrase "personal piety" (persönliche Frömmigkeit) ${ }^{124}$. He argues using examples of inscriptions from Dacia and Moesia Inferior, where the personal motivations of the dedicators are obvious. In the inscriptions dedicated to Jupiter and Juno in Moesia Inferior, one is fulfilled ex visu (the one of Maximus, magister vici ${ }^{125}$ ). It must be underlined that Maximus uses the formula pro salute Imp. and mentions his position of village mayor. Hence, he definitely had personal reasons. D. Fishwick has doubts concerning the sincerity of the dedicators when expressing their vows for the health of emperors ${ }^{126}$. Nonetheless, whereas there are many texts where personal piety is apparent, certain texts (mostly those from the north of the province) have an official character; the inscriptions were set up by the magistri

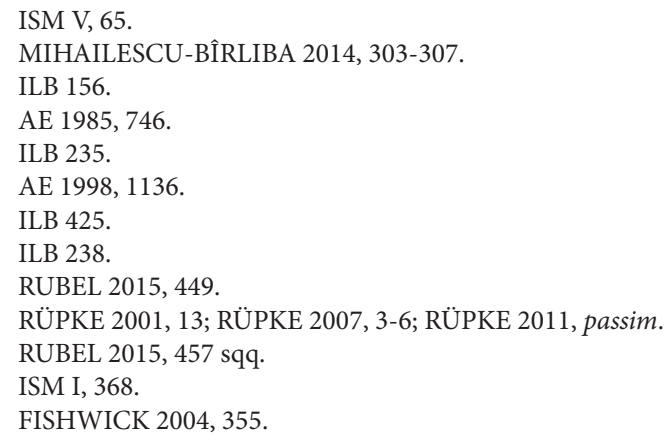

vici on behalf of their communities. This is why I divided the vows into collective and individual vows. I add here another criterion for division, by the character of the text: official and private. This is another translation of the dichotomy "State religion" - "personal piety".

An interesting aspect of these vows is represented by the language of the inscriptions. Many texts have numerous errors, which stands to prove that the lapicides were not highly educated people, that they did not know Latin very well and that they were maybe indigenous people. Consequently, such errors are indirect proof that the inscriptions were actually drafted up in the rural setting. In this respect, I mention grammar errors (vicus Secundini ${ }^{127}$, Ulmetum ${ }^{128}$, vicus Celeris) ${ }^{129}$ and spelling errors (vicus Secundini ${ }^{130}$, Ulmetum $^{131}$, vicus Turris Muca[---] ${ }^{132}$, Dermanci ${ }^{133}$, Dolna Bešovica $^{134}$, Capidava ${ }^{135}$, Sacidava ${ }^{136}$. The most striking example thereof is the one of Sacidava where, despite the fact that the commissioner is a former duumvir, the text has a spelling error. Such errors also indicate that the dedicators commissioned the texts in Latin: some of them were Latinspeaking and those who were not did their best to express their attachment to the Roman State through their vows.

Concerning the other Roman provinces, there are numerous vows for Jupiter and Juno fulfilled in the rural areas (collective and individual, official and personal). In Upper Germany, the vicani salutares (near Mainz) dedicated an altar to the divine couple ${ }^{137}$, just like the vicani Mogontiacenses vici novi $^{138}$ and two more persons within the same village ${ }^{139}$. There are other vows in the rural areas in a potential vicus Victorum (also on Mainz) ${ }^{140}$, in the civitas Mattiacorum ${ }^{141}$ or in the modern-day villages of Jagsthausen ${ }^{142}$, Heddernheim ${ }^{143}$ and Niedernberg ${ }^{144}$. It should also be stated that the popularity of this divine couple in the military setting of Upper Germany is also highlighted by the inscriptions of Osterburken ${ }^{145}$, Großkrotzenburg $^{146}$, Mainz-Kastell ${ }^{147}$, Amorbach ${ }^{148}$, Gundelsheim $^{149}$, Jagsthausen ${ }^{150}$ etc. Concerning the civilian setting, O. Schipp observes for Upper Germany that, until mid second century, the dedicators belong to the Roman culture (Roman citizens or Latin-speaking people who had immigrated from other provinces) ${ }^{151}$. In Lower Germany,
127 ISM I, 349.
128 ISM V, 64, 69
129 ISM I, 351.
130 ISM I, 346, 347
131 ISM V, 62, 63
132 ISM II, 141
133 ILB 192.
134 ILB 156
35 ISM V, 13, 14, 23
136 AE 1963, 175
137 CIL XIII 6723.
138 CIL XIII 6722.
139 CIL XIII 7270.
140 SCHILLINGER-HÄFELE 1977, no 91.
141 CIL XIII 7266; FINKE 1927, no 204.
142 CIL XIII 6555.
143 CIL XIII 7353.
144 CIL XIII 7736a.
145 AE 1996, 1152, 1157, 1160, 1163; CBI 146-149, 155, 164, 169, etc.
146 SCHILLINGER-HÄFELE 1977, no. 127-128.
147 CIL XIII 7269, 7273.
148 CIL XIII 11771
149 CIL XIII 6485.
150 CIL XIII 6556-6557.
151 SCHIPP 2016, 49. 
there are also inscriptions dedicated to Jupiter and to Juno in the rural setting ${ }^{152}$, as well as in Gallia ${ }^{153}$. The Danubian provinces (the Pannonias ${ }^{154}$ and the Dacias ${ }^{155}$ ) also provide such examples.

Therefore, it is worth noting the dissemination of the cult of this divine couple throughout the entire Roman rural setting, but it appears to me that the most numerous occurrences are found in the provinces bordering the Barbaricum. In any case, the dedicators are usually soldiers or veterans with properties in the rural area, but in Upper Germany, numerous texts are set up by civilians (collective and individual vows). The reason is the same one as invoked by D. Fishwick: a manifestation of loyalty for the State, of belonging to the Roman structures: Jupiter and Juno also represented the imperial couple, a symbol of stability and power.

\section{CONCLUSIONS}

The vows for Jupiter and Juno in the rural areas of Moesia Inferior are numerous, but I have concluded that the northern part of the province provides a far richer documentation than the rest of the province. The collective and official dedications are also more numerous in the north of Moesia Inferior. As for all texts dating to the second century, even to the second quarter of this century, I believe that an explanation may be found in the changes that occurred in the rural areas of this region. The deep transformation of the village landscape is marked, in my opinion, by the campaigns conducted by Trajan in Moesia Inferior against the Dacians and their allies. I note here that the military reorganisation of the province under Trajan is only the beginning of a new wave of personnel for the campaigns, the effects of which will be visible later. Indeed, after the first Dacian war, Trajan orders the transfer of the fifth legion Macedonica to Troesmis and reinforces the Danube line, in its northern sector, with camps and castella. This initiative has as consequence a stronger presence of soldiers and then of veterans in the rural areas of the province. In my opinion, during the reign of Trajan, they organised the regio Histriae, a structure different from the territorium, to allow the colonisation of the Roman citizens, of the veterans and of certain Thracians ${ }^{156}$. I believe that the foundation of the vici organised according to the Roman model - sometimes comprising conventi of former soldiers, of citizens and of Thracians colonised from other regions - dates from the reign of Hadrian. Thus, in this respect I agree with $\mathrm{A}$. Ibba (who fails to provide a reason for his choice) ${ }^{157}$, not with M. Bărbulescu and L.Buzoianu (who believe this process began during the reign of Antonine) ${ }^{158}$. It is true that the first texts date to Antonine's reign, but taking into account that the first soldiers of this region completed their service during the reign of Hadrian (some of them during Trajan), I think a more practical solution was the organisation during the reign of Trajan's successor.

\footnotetext{
152 CIL XIII 8495, 8589, 8809, 8811.

153 CIL XII, 996; XIII 3606, 4039, 4573; AE 1941, 155. See also MOITRIEUX 2011, 232-253.

154 CIL III 3626, 15179; RIU 356, 639, 642, 664, 722, 950; AE 2010, 1247.

155 CIL III 7627; IDR III/3, 94; III/4, 247.

156 See mostly AVRAM 2007, 99.

157 IBBA 2016, 372.

158 BĂRBULESCU/BUZOIANU 2015-2016, 199.
}

Moreover, at Troesmis there is a list of soldiers discharged in $134^{159}$, which confirms my assumption. At this point, a rich documentation is available concerning not only the organisation of villages, but also the population. There is no good reason to believe, against the arguments of A. Ibba, that the rural areas of Istros were less populated ${ }^{160}$, given that the ancient Greek forms of organisation for the territories of Istros $^{161}$ and of Tomis ${ }^{162}$ attest the presence of the Greeks and probably of the locals. This was more of an epigraphic habit emerging concomitantly with the Roman presence. The rural areas within the southern part of the province also record vows for Jupiter and Juno, but such vows are mostly individual, because the veterans or the other citizens, if they resided in the rural area, did not gather to form conventi. As I stated above, this organisation began right after the reign of Trajan, after the reorganisation of the northern Danube line.

The vows have an official character, sometimes fulfilled by the rural communities, but also private (an expression of "personal piety"). The inscriptions for this divine couple set up in the rural areas of other Western provinces show the same form of expressing public loyalty, as stated earlier: attachment to the Roman State, to the emperor and to his family, as elements of stability, power and prosperity. Furthermore, in the text of Gălbiori - along with the one of Capidava - the magister vici Veturius Tertius associates the cult with that of Ceres Frugifera ${ }^{163}$.

One last aspect: this cult was part - if not of the Romanisation - at least of the Latinisation of the province. Paradoxically, linguistic errors show this aspect: the commissioners insisted on having their vows written in Latin, as a sign that they belonged to the Empire.

\section{ACKNOWLEDGEMENT.}

This work was supported by a grant of Ministry of Research and Innovation, CNCS-UEFISCDI project PNIIIP4-ID-PCE-2016-0550.

\section{REFERENCES}

$\mathrm{AE}$

L’Année Épigraphique, Paris.

\section{APARASCHIVEI 2015}

Aparaschivei, D., Some Remarks Concerning the Rural Vici and Their Administration in Moesia Inferior Province. In: Cociş, S., Lăzărescu, V.-A., Gui, M., Deac, D. (eds.), Ad finem Imperii Romani. Studies in Honour of Coriolan H. Opreanu (Cluj-Napoca: Mega), 27-43.

\section{AVRAM 2007.}

Avram, A., Les ciues Romani consistentes de Scythie Mineure: État de la question. In: CompatangeloSossignan, R./Schwentzel, G.-Chr. (eds.), Étrangers dans la cité romaine. Actes du colloque de Valenciennes (14-15 octobre 2004) „Habiter une autre patrie: des incolae de la République aux peuples fédérés du Bas-Empire" (Rennes: Presses universitaires de Rennes), 91-107.

\section{BĂRBULESCU/BUZOIANU 2013}

Bărbulescu, M./Buzoianu L., Teritoriul Tomisului în epoca romană timpurie în lumina documentelor epigrafice. I. In: Panait Bîrzescu F., Bîrzescu, I., Matei-Popescu, F., Robu,
159 ISM V, 137
160 IBBA 2016, 370.
161 ISM I, 378.
162 BĂRBULESCU, RĂDULESCU 1994, 168-170.
163 ISM V, 56. 
A. (eds.), Poleis în Marea neagră. Relaţii interpontice și producţii locale (București: Humanitas), 174-202.

BĂRBULESCU/BUZOIANU 2015-2016

Bărbulescu, M./Buzoianu L., Localités rurales du territoire de Tomis aux noms antiques inconnus: quelques observations sur l'onomastique, Pontica 48-49, 415-427.

BĂRBULESCU/BUZOIANU 2016

Bărbulescu, M./Buzoianu L., Observations sur la population dans le territoire de Tomis à l'époque romaine (Ier-IIIe s. ap. J.-C.), Ancient West \& East 15, 195-212.

BĂRBULESCU/RĂDULESCU 1994

Bărbulescu, M./Rădulescu, A., Inscripții inedite din Tomis BÂLTÂC 2011 și din împrejurimi, Pontica 27, 157-171.

Bâltâc, A., Lumea rurală în provinciile Moesia Inferior şi Thracia (sec. I-III p. Chr.) (București: Muzeul Național de Istorie a României).

BOTTEZ 2014

Bottez, V., Three New Inscriptions from Istros, Dacia N. S. 58, 2014, 285-292.

CBI.

Der römische Weihebezirk von Osterburken I: Corpus der griechischen und lateinischen Beneficiarier-Inschriften des Römischen Reiches (Stuttgart: K. Theiss).

CIL

Corpus Inscriptionum Latinarum (Berlin).

CÎRJAN 2004

Cîrjan, R., Tropaeum Traiani: un municipe de droit latin en Mésie Inférieure, Ephemeris Dacoromanae 12, 51-59.

COVACEF 2000

Covacef, Z. Cohors I Germanorum à Capidava. In: Moga, V., Ciugudean, H., Army and Urban Development in the Danubian Provinces of the Roman Empire. Proceedings of the International Symposium - Alba Iulia 1999 (Alba Iulia: Muzeul Național al Unirii Alba Iulia), 285-291.

DORUŢIU-BOILĂ 1964

Doruțiu-Boilă, E. Precizări topografice despre unele inscripții dobrogene, Studii şi cercetări de istorie veche şi arheologie 15, 131-135.

FINKE 1927

Finke, H. Neue Inschriften, Bericht der RömischGermanischen Komission 17, 1-107.

FISHWICK 2004

Fishwick, D. The Imperial Cult in the Latin West, III/3, The Provincial Cult. Provincial Centre; Provincial Cult (LeidenBoston: Brill).

IGLNovae

Inscriptions grecques et latines de Novae (Bordeaux: Ausonius).

ILB

Inscriptiones latinae in Bulgaria repertae (Sofia: Kliment Ohridski).

ISM

IBBA 2016

Inscriptiones Scythiae Minoris (Bucharest-Paris Editura Enciclopedică - De Boccard).

Ibba, A., Agglomerati pre-urbani nelle Moesiae (I-III secolo): riflessioni e confronti. In: Mainardis, F. (ed.), "Voce concordi". Scritti per Claudio Zaccaria (Trieste: Editreg), 361-375.

KOVÀCS 2013

Kovács, P., Territoria, pagi and uici in Pannonia. In: Eck, W., Fehér, B., Kovács, P. (eds.), Studia epigraphica in memoriam Géza Alföldy (Bonn: Habelt), 131-154.

MATEI-POPESCU 2010

Matei-Popescu, F., The Roman Army in Moesia Inferior
(Bucharest: Conphys Publishing House).

MIHAILESCU-BÎRLIBA 2014

Mihailescu-Bîrliba, L., Une nouvelle inscription de Topolog (Mésie Inférieure), Dacia N. S. 58, 303-307.

MIHAILESCU-BÎRLIBA 2015a

Mihailescu-Bîrliba, L., Le culte de Jupiter et de Junon en Mésie Inférieure: le témoignage d'une nouvelle inscription. In: Zerbini, 1. (ed.), Culti e religiosità nelle province danubiane. Atti del II Convegno Internazionale Ferrara 2022 Novembre 2013 (Bologna: I libri di Emil), 439-445.

MIHAILESCU-BÎRLIBA 2015B

Mihailescu-Bîrliba, L., Colonization in the VICVS ULMETVM during the Early Roman Empire. In: Mihailescu-Bîrliba, L. (ed.), Colonization and Romanization in Moesia Inferior. Premises of a Contrastive Approach (Kaiserslautern und Mehlingen), 143-155.

\section{MIHAILESCU-BÎRLIBA/DUMITRACHE 2012}

Mihailescu-Bîrliba, L./Dumitrache, I., La colonisation dans le milieu militaire et le milieu civil de Troesmis (Iaşi).

MOITRIEUX 2011

Moitrieux, G., Un nouveau vicus vénète honore Jupiter. In: Deroux, C. (ed.), Corolla Epigraphica. Hommage au professeur Yves Burnand I (Bruxelles), 232-253.

\section{MUNTEANU 1970}

Munteanu, M., Cu privire la organizarea administrativă a teritoriului capidavens (sec. I-III), Pontica 3, 211-222.

NEMETI 2015

Nemeti, S., Vota pro salute imperatoris in Dacia, Classica \& Christiana 10, 251-262.

NUŢU/MIHAILESCU-BÎRLIBA 2017

Nuțu, G./Mihailescu-Bîrliba, L., Topolog: des nouvelles informations archéologiques et épigraphiques sur la colonisation romaine dans le milieu rural du nord-est de la Mésie Inférieure. In: Mihailescu-Bîrliba, L. (ed.), Migration, Kolonisierung, Akkulturation im Balkanraum und im Osten des Mittelmeerraumes (3. Jh. v. Chr.-6 Jh. n. Chr.) (Konstanz: Hartung-Gorre Verlag), 171-175.

\section{OPRIŞ 1997}

Opriș, I. C., O nouă mărturie epigrafică privitoare la satționarea cohortei I Ubiorum la Capidava, Studii și cercetări de istorie veche și arheologie 48,277-281.

OPRIŞ/POPESCU 1997

Opriș, I. C./Popescu, M. Un nouveau préfet de cohorte à Capidava, Pontica 30, 177-181.

RIU

\section{RUBEL 2015}

Die römischen Inschriften Ungarns (Budapest).

Rubel, A. 2015. Persönliche Frömmigkeit und 'Staatsreligion'. Grundsätzliche Überlegungen zum Wesen der römischen Religion am Beispiel von Votivinschriften aus Dakien und Moesia Inferior. In: Zerbini, L. (ed.), Culti e religiosità nelle province danubiane. Atti del II Convegno Internazionale Ferrara 20-22 Novembre 2013 (Bologna: I libri di Emil), 447-472.

RÜPKE 2001

Rüpke, J. Die Religion der Römer. Eine Einführung (München: Cambridge University Press).

RÜPKE, 2007

Rüpke, J. Roman Religion - Religions of Rome. In: Rüpke, J. (ed.), A Companion to Roman Religion (Oxford-Malden: Blackwell), 1-9.

RÜPKE 2011

Rüpke, J., Aberglauben und Individualität. Religiöse Abweichung im römischen Reich (Tübingen: Mohr Siebeck).

SCHILLINGER-HÄFELE 1977 
Schillinger-Häfele, U., Vierter Nachtrag zu CIL XIII und zweiter Nachtrag zu Fr. Vollmer, Inscriptiones Bavariae Romanae. Inschriften aus dem deutschen Anteil der germanischen Provinzen und des Treverergebietes sowie Rätiens und Noricum, Bericht der Römisch-Germanischen Komission 58,2, 447-604.

\section{SCHIPP 2016}

Schipp, O., Götter in der Provinz. Eine Untersuchung der Weihinschriften in der nördlichen Germnia superior und in der östlichen Gallia Belgica (Gutenberg: Computus Druck Satz \& Verlag).

\section{VAN ANDRINGA 2003}

Van Andringa, W., Cités et communautés d'expatries installées dans l'Empire romain: le cas descives Romani consistentes. In: Belayche, N., Mimouni, S. C. (eds.), Les communautés religieuses dans le monde gréco-romain. Essais de définition (Turnhout: Brepols), 49-60.

VISY 2009

Visy, Zs., Presidia et burgi in the Early Roman Empire. In: Morillo, A., Hanel, N., Martin, E. (eds.), Limes 20. Estudios sobre la Frontera Romana, Roman Frontier Studies, III, León, Spain, September 2006 (Madrid: Consejo Superior de Investigaciones Científicas, Instituto Histórico Hoffmeyer: Polifemo), 989-996. 